\title{
EFFECT OF PILE SYSTEM CHARACTERISTICS ON THE CAISSON BREAKWATER EFFICIENCY AND SEABED CHANGES
}

\author{
ثأثير خصائص النظام المحازوقي على كفاءة حاجز الأمواج القيسولي و تغيرات القاع
}

\author{
Heikal E. M. ', Salem T.N. ${ }^{2}$ and Koraim A.S. ${ }^{3}$
}

I- Asso. Prof., Water Eng. Dept, Zagazig Univ., Zagazig, Egypt

2- Asso. Prof., Structural Eng. Dept, Zagazig Univ., Zagazig. Egyp1

3- Ph.D. Student, Water Eng. Depl, Zagazig Univ.. Zagazig. Egypl

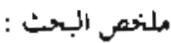

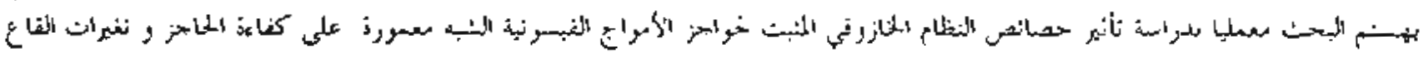

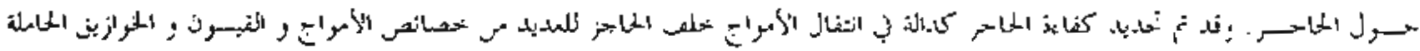

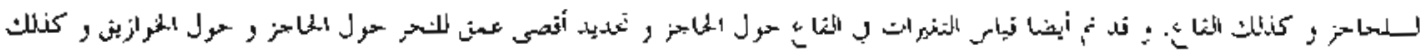

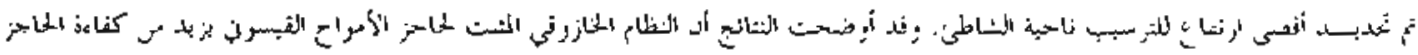

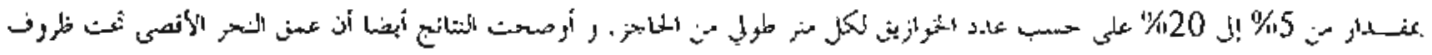

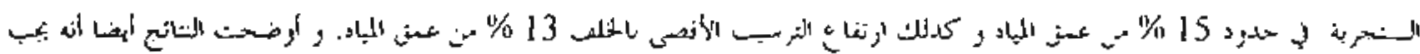

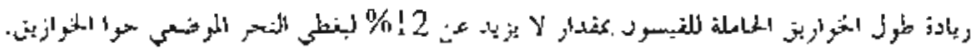

\begin{abstract}
:
This paper presents the results of an experimental investigation on the effect of the characteristics of the supporting pile system which fixes the seni-immersed caisson breakwater on the breakwater efficiency and seabed changes. The efficiency of the breakwater was presented as a function of wave transinjssion for differen wave . caisson. supporing pile systert and seabed parameters. Also, the salndy bed hydrograplyy was recorded around the breakwater and the maximum erosion and accretion were determined. It is concluded that the supporting pile system increases the efficiency of the caisson breakwater by $51020 \%$ according to the number of piles per unit length of the breakwater. Also, the maximum erosion depth and the maximum accretion hejght near the structure were found $15 \%$ and $13 \%$ relative to the water depth. Finally, the imbedded lengh of the supporting piles inust be increased by $12 \%$ to cover the local scour around the piles.
\end{abstract}

\section{INTRODUCTION:}

The caisson structurc extending from above the water surface to some distance below and supporting on a system of piles may be considered as a partially wave barrier. This breakwater model may be used for coastal protection to control the wave height shoreward. This breakwater was successfully employed for different wave energy applications. The control of

Accepted February 26, 2006 
wave field near the shores tends to control the sea bed stability and the shore line response. Seabed stability is a major concem in the desigu of many marine struclures. Considerable researches were devoted to analyze the efficiency of this breakwater type and the seabed changes around it.

The performance of the rectangular semi-immersed body was studied experimentally and theoretically by Carr (1952), Macagno (1953), Mc-Dougal, and Sulisy (1989), Mani (1991), Gesrahab (1995), Mani and Murali (1997), Sundar and Subbarao (2003) Heikal (2004) and Heikal and Koraim (2004).

Sumer et al. (1992) and Kobayashi and Oda (1994) studied the scour around single piles. Chow and Herbich (1978) studied the scour around six-, four-, and three-legged pile structures. Sumer and Fredsqe (1993) and (1998) and Bayram and Larson (2000) sludied the wave scour around a group of vertical piles.

Mc-Dougal, and Sulisy (1989) examined the effects of fixed and floating structures on sea bed stability. They modeled the soil as a poro-elastic continuum using Biot Consolidation theory.

Heikal E.M. (2004) investigated the wave field (patteri) and local scour at semi-immersed body fixed on pile system experimentally. The wave height and the seabed configuration are measured along the bed for intermediate and long water waves.

In this paper the effect of the characteristics of the supporting pile system which fixes the semi-immersed caisson breakwater on the breakwater efficiency and seabed changes investigated experimentally with wide range of wave and structural conditions. The effect of the supporting pile spacing and diameter on the breakwater efficiency and scour near the breakwater were studied. Also, the seabed configuration was measured along the bed for different water waves and structure conditions. Different wave frequencies, relative structure dimensions and bed material properties were taken into considerations.

\section{EXPERIMENTAL WORK:}

Those expcriments were carried out in a wave llume of $\mathrm{i} 2 \mathrm{~m}$ length, $0.45 \mathrm{~m}$ depth and $0.30 \mathrm{~m}$ width. The variable speed flap type wave generator was used to generate wave periods ranged between 0.66 and 2.86 seconds will stroke distance of 22 $\mathrm{cm}$ as shown in figure (1). The mean water depth was held colsstant at $20 \mathrm{~cm}$. The dimensions and details of the models tested on solid bed are presented in table (I) and figure (2).

There were three tested models lested on movable sandy becl. The first model parameters were $B / h=1.0$ and $D / h$ $=0.2$ with supporting pile system of $\mathrm{d} / \mathrm{h}=0.16$ and $\mathrm{G} / \mathrm{h}=0.5$. The second mode] parameters were $B / h_{1}=1.0$ and $D / h=0.4$ with supporting pile system of $d / h=0,16$ and $G / h=0.5$. The third model was a caisson supported on a large spaced pile system and its parameters ware $B / h_{1}=1.0$ and $D / h=0.4$. The characteristics of the breakivaler models and the datum of the bed topography are shown in figure (3). The grain size of sand was $\mathrm{d}_{50}=0.30 \mathrm{~mm}$. The bed topography around and under the tested breakwater models was recorded for the equilibrium erosion and accretion using linear scale (point gauge).

\section{EXPERIMENTAL ANALYSIS:}

The breakwater efficiency as a function of the transmission coefficient $\left(k_{f}\right.$ 
Mansoura Engireering Journal, (MEJ), Vol. 31, No. 1, March 2006.

Table (1) The dimensions and details of the models tested on solid bed.

\begin{tabular}{|c|c|c|}
\hline Parameter & The ranges & Notes \\
\hline Breakwater Width (B) (cm) & 20 and 30 & \\
\hline Breakwater Draft (D) (cm) & $0,4,8,12$ and 16 & \\
\hline Pile Diameter (d) (cm) & 3.3 and 4.9 & \\
\hline Pile Spacing (G) (cm) & $7.5,15$ and 30 & Perpendicular to wave direction \\
\hline Pile Spacing (S) (cm) & 10 & Parallel to the wave direction \\
\hline Bed Slope (s $\left(\mathrm{c}_{\mathrm{b}}\right)$ & $0 \%, 1 \%$ and $2 \%$ & For solid bed \\
\hline
\end{tabular}

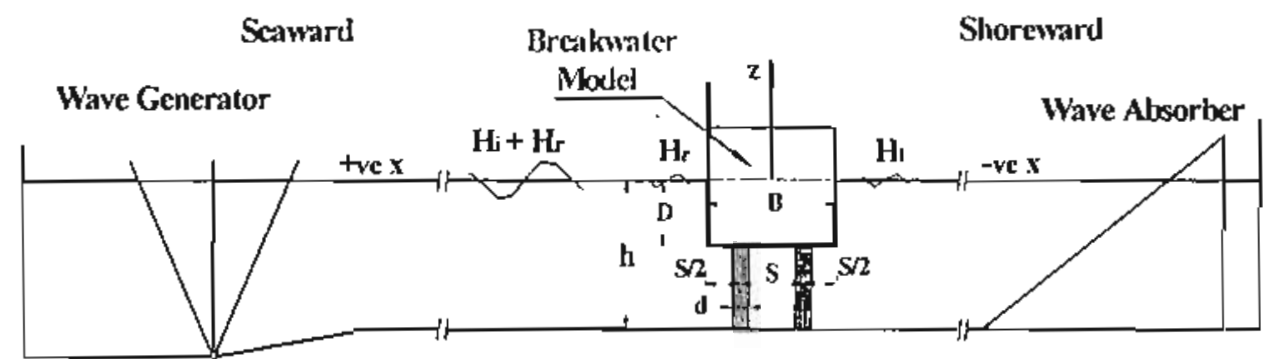

Fig.(I) Definition Sketch of the Tested Model in the Wave Flume.
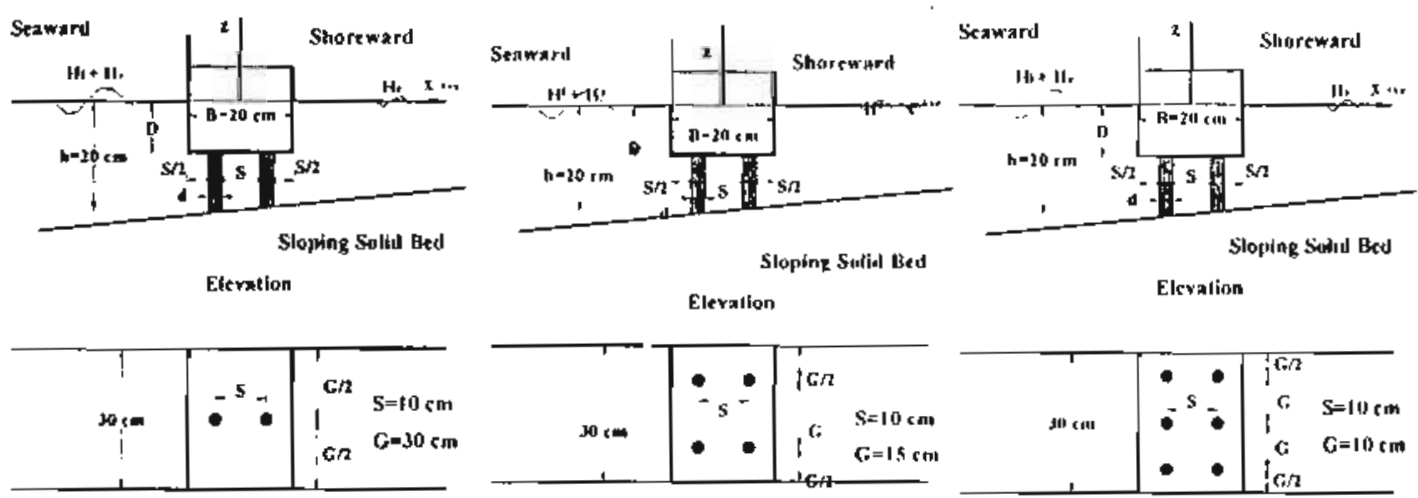

Elcvalion

Plan

Plan

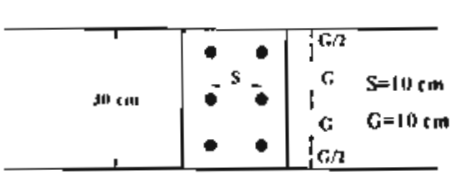

Plign

Fig. (2) The Details of the Modeis Fixed on Pile System on Sloping Solid Bed
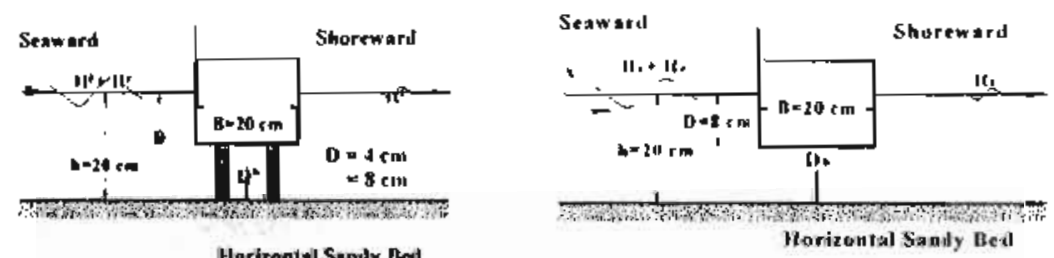

Horizontal Sandy Ded

Elevalion

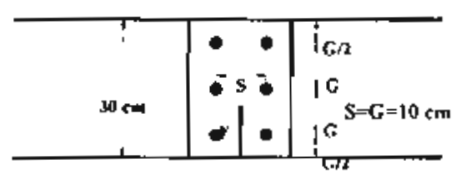

Erevalion

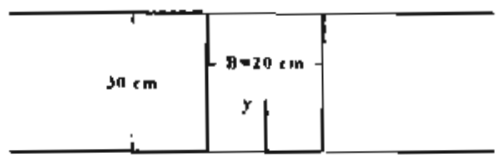

$\ln$

P"Ian

Fig. (3) The Details of the Models on the Movable Sandy Bed 
$\left.=H_{6} / H_{i}\right)$ may be dependent upon the following non-dimensional parameters:

$$
k_{4}=f_{l}\left(H_{i} / L, l / L, D / L, B / L, G / L, d / L, S / L\right. \text {, }
$$

In which $\mathrm{H}_{4}$ is the transmitted wave height, $\mathrm{H}_{\mathrm{i}}$ is the incident wave height and $\mathrm{L}$ is the wave length.

Also, the equilibrium erosion depth " $D_{s}$ " and accretion height " $D_{4}$ " were obtained when the sediment transport in the scour area was equal to the sediment transport far from the structure (live bed case) and may be dependent upon the following non-dimensional parameters:

$$
\begin{aligned}
& \frac{D_{s}}{h}=\phi_{1}\left(\frac{H_{l}}{H_{i}}, \frac{H_{r}}{H_{i}}, k h, \frac{D}{h}, 0\right) \\
& \frac{D_{d}}{h}=\phi_{2}\left(\frac{H_{i}}{H_{i}}, \frac{H_{r}}{H_{i}}, k l,, \frac{D}{h}, 0\right)
\end{aligned}
$$

In which $H_{r}$ is the reflecled wave height, $k$ is the wave number $(k=2 \pi / L)$, and 0 is the shield's parameter and defined as follows:

$$
\begin{aligned}
& 0=\frac{U_{f m}^{2}}{\left(s_{r}-1\right) g_{50}} \\
& U_{f m}=\sqrt{\frac{f}{2}} U_{m} \\
& f=\frac{2}{R_{n}^{1 / 2}} \\
& R_{I 1}=\frac{U_{m} d}{v}
\end{aligned}
$$

In which,$s_{\mathrm{r}}$ is the sediment relative density, $U_{\mathrm{fm}}$ is the maximum value of the undisturbed bed shear velocity, $f$ is the friction coefficient, $U_{m}$ the maximum orbital velocity $\left(U_{m}=\omega a\right)$, $\omega$ is the angular wave frequency $(\omega=2 \pi / T)$, $a$ is the wave amplitude $\left(a=H_{i} / 2\right), \quad R_{n}$ is Reynolds's number, and $v$ is the kinamatic viscosity of water at $20^{\circ} \mathrm{c}\left(10^{-2} \mathrm{~m}^{2} / \mathrm{sec}\right.$. $)$.

Figure (4) presents the effect of the relative pile diameter $(\mathrm{d} / \mathrm{h})$ and the dimensionless wave number $(\mathrm{kD})$ on the transmission coefficient $\left(k_{1}\right)$. This is when $\mathrm{B} / \mathrm{h}=1.0$ and $\mathrm{G} / \mathrm{h}=0.5$ for different seabed slopes. The figure shows that the transmission coefficient decreases as the increase of $\mathrm{kD}$ and $\mathrm{d} / \mathrm{h}$. Also, the effect of the relative pile diameter $(d / h)$ on the transmission coefficient decreases as $\mathrm{kD}$ increases. In which the breakwater cfliciency increases with a value less than $8 \%$ when the $\mathrm{d} / \mathrm{h}$ increases from 0.16 to 0.25 . While the efficiency of the caisson fixed on the pile system is more than the efficiency of the fixed floating model (without piles) by about 5 10 20\%. By comparing figures (4a), (4b) and (4c), the efficiency of the breakwater increases as the seabed slope decreases.

Figure (5) presents the effect $d / h$ and $\mathrm{kD}$ on $\mathrm{k}_{\mathrm{l}}$ when $\mathrm{B} / \mathrm{h}=1.0$ and $\mathrm{G} / \mathrm{h}=$ 0.75 for different seabed slopes. The figure shows that the transmission coefficient decreases as the increase of $\mathrm{kD}$ and $d / l$. Also, the effect of the relative pile diameter $(d / h)$ on the transmission coefficient decreases as $\mathrm{kD}$ increases. In which the breakwater efficiency increases with a value less than $5 \%$ when the $\mathrm{d} / \mathrm{h}$ increases from 0.16 to 0.25 . While the efliciency of the caisson fixed on the pile system is more than the efficiency of the fixed floating model (without piles) by about 5 to $10 \%$.

Figure (6) presents the effect $d / h$ and $k D$ on $k_{1}$ when $B / h=1.0$ and $G / h=1.5$ for different seabed slopes. The figure shows that the transmission coefficient decreases as the increase of $\mathrm{kD}$ and $\mathrm{d} / \mathrm{h}$. Also, the breakwater efficiency increases with a small values as $d / h$ increases. By comparing the figures (4) to (6), the 


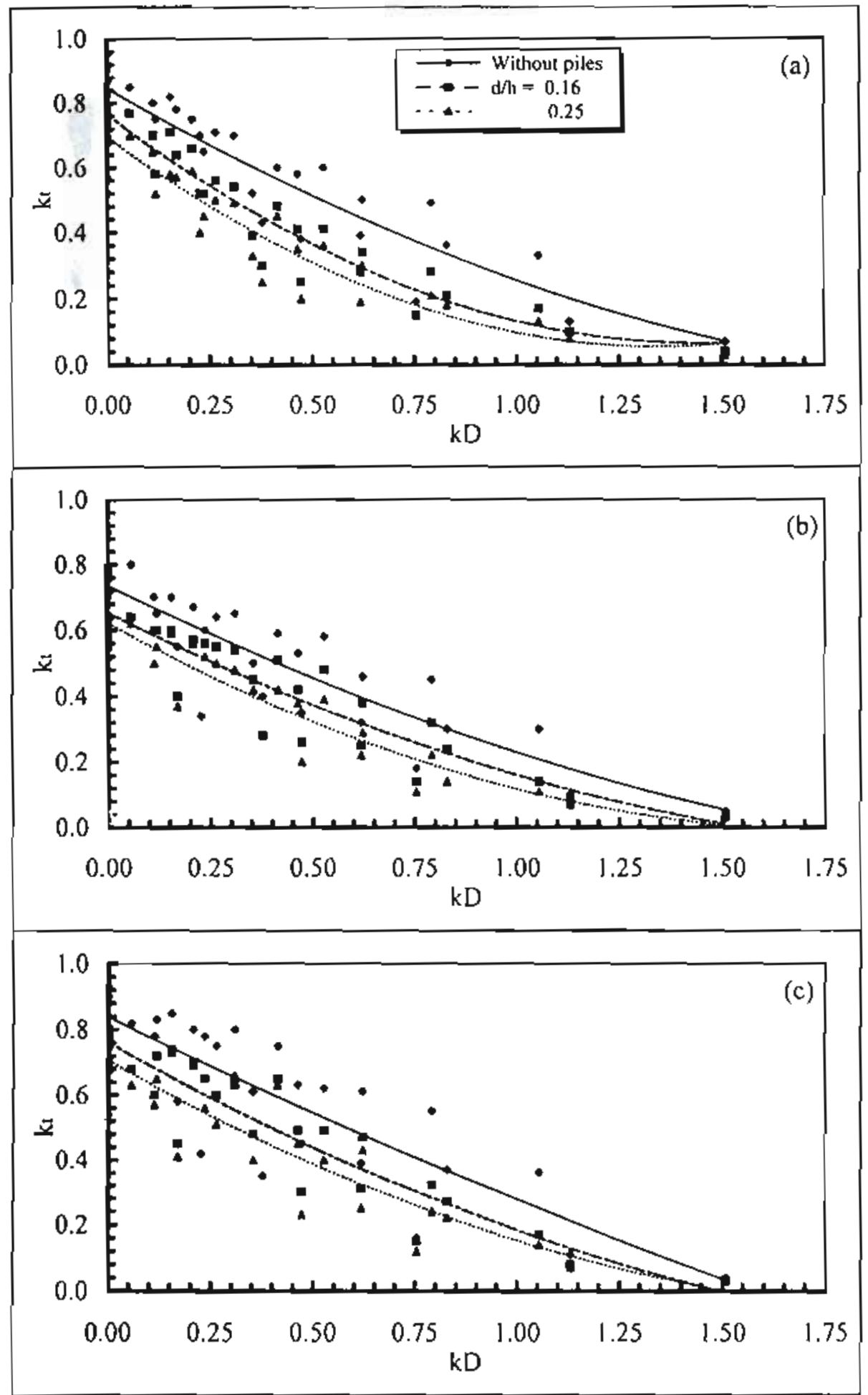

Fig.(4) The Effect of the Ratios (d/h) and (kD) on the Wave Transmission when $B / h=1.0$ and $G / h=0.5$ for Different Bed Slopes:
(a) $\mathrm{s}=0 \%$
(b) $\mathrm{s}=1 \%$
(c) $5=2 \%$ 


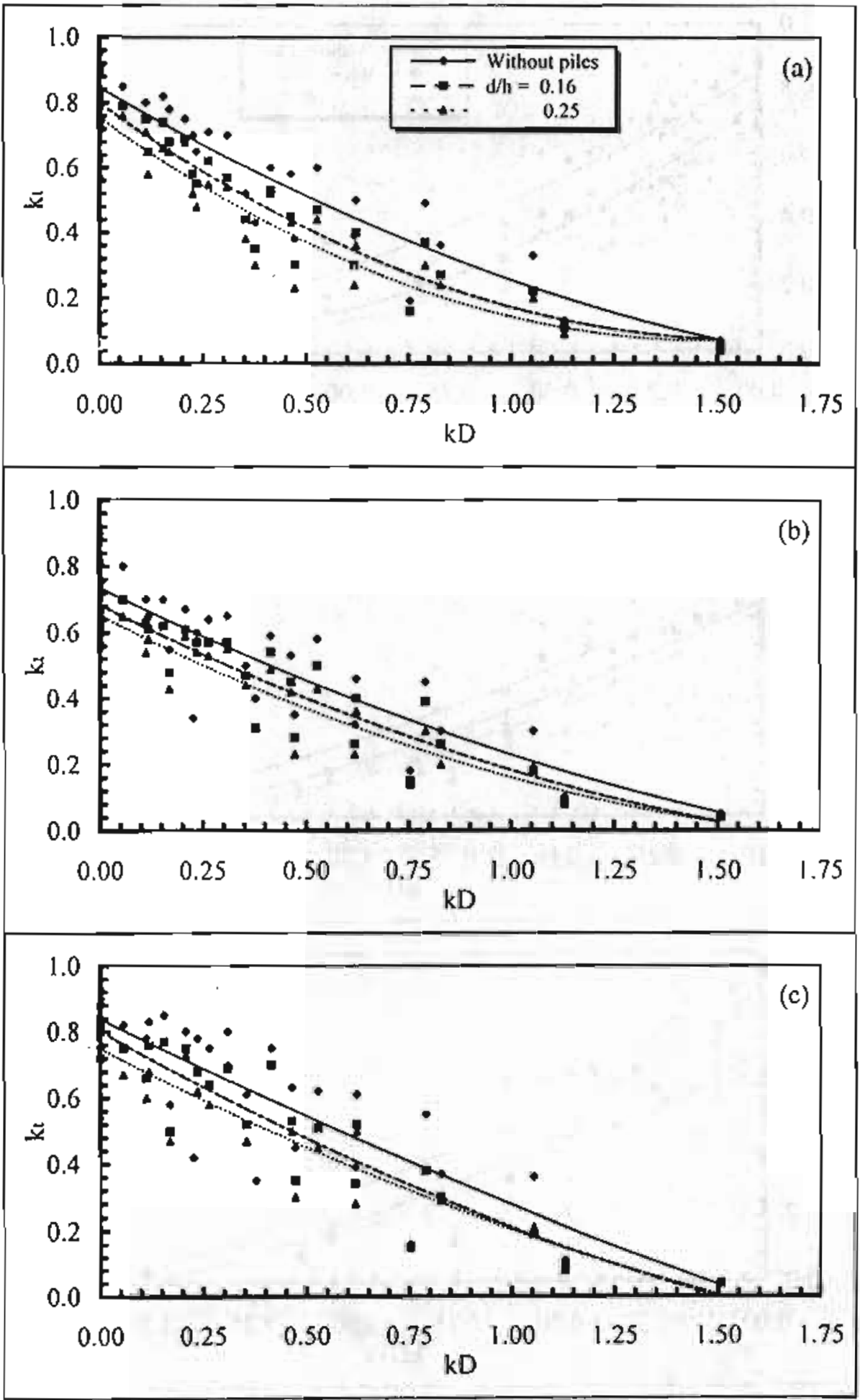

Fig.( 5 ) The Effect of the Ratios ( $/ / h$ ) and (kD) on the Wave Transmission when $B / h=1.0$ and $G / h=0.75$ for Different Bed Slopes:
(a) $\mathrm{s}=0 \%$
(b) $\mathrm{s}=1 \%$
(c) $\mathrm{s}=2 \%$ 


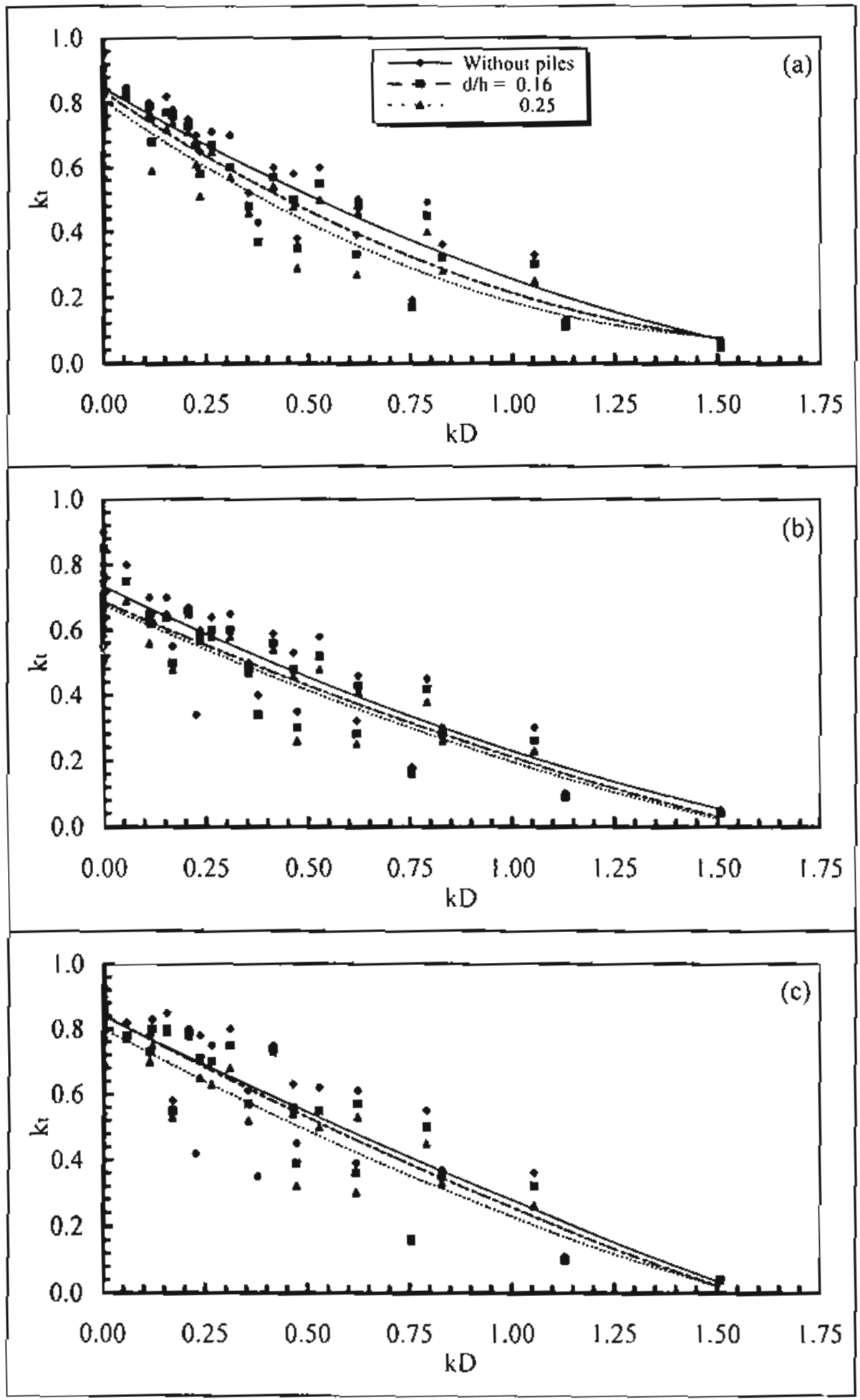

Fig.(6) The Effect of the Ratios (d/h) and (kD) on the Wave Transmission when $B / h=1.0$ and $G / h=1.5$ for Different Bed Slopes:
(a) $\mathrm{s}=0 \%$
(b) $\mathrm{s}=1 \%$
(c) $\mathrm{s}=2 \%$ 
supporting pile system increases the efficiency of the caisson breakwater by 5 to $20 \%$ according to the number of piles per unit length of the breakwater.

For the semi-immersed caisson breakwater, a partial standing wave, which formed due to the interaction of the incident and the reflected wave heights is developed and the maximum bottom pressure occurs at the antinodes of the standing wave. The maximum pressure occurs under the structure and large velocities are developed under the structure greater than the amplitude of the incident wave bottom velocity. The most important transporting term is probably the wave orbital velocity [8].

Figures (7) to (9) present the contour maps of the seabed around and under the breakwater for different wave and structural conditions. Figure (7) shows the effect of the three breakwater models on the seabed deformation when the dimensionless wave number (kh) is 1.32 . It is clear that the maximum seabed erosion occurs under the seaward lip of structure especially for the first and the second models, figures (7a) and (7b). While the maximum seabed erosion occurs at relative distance of $x / L=0.25$ for the third model figure $(7 \mathrm{c})$. Also, the maximum seabed accretion occurs shoreward structure especially for the first and the second models. While the effect of the third model on the seabed shoreward structure is very small and it can be neglected. The maximum relative seaward erosion depth, scour hole length and shoreward accretion height $\left(\mathrm{D}_{\text {smax }} / \mathrm{h}, \mathrm{I}_{\text {smax }} / \mathrm{L}\right.$ and $\left.\mathrm{D}_{\mathrm{dmax}} / \mathrm{h}\right)$ are $0.075,0.15$ and 0.075 for the first model, $0.1,0.16$ and 0.05 for the second model and $0.06,0.12$ and 0.01 for the third model.

Figure (8) shows the effect of the three breakwater models on the seabed deformation when the dimensionless wave number $(\mathrm{kh})$ is 0.8 . The figure slows that the maximum seabed erosion occurs at a distance from the seaward tip of structure. Also there is small erosion zones occur around the supporting piles. Also, the figures show that accretion zones occur at different locations. For the first model, the maximum relative seaward erosion depth. and length $\left(D_{\text {smax }} / \mathrm{h}, l_{\text {smax }} / \mathrm{L}\right)$ are 0.12 and 0.16 . Also, the maximum relative erosion depth, and length around the supporting piles $\left(D_{\text {smax }} / h, 1_{\text {snax }} / \mathrm{L}\right)$ are 0.03 and 0.06 . Asso, the maximum shoreward accretion height $\left(D_{d m a x} / h\right)$ is 0.05 . For the second model, $\mathrm{D}_{\text {smax }} / \mathrm{h}$ and $\mathrm{I}_{\mathrm{smax}} / \mathrm{L}$ seaward are 0.11 and 0.12 . Also, $D_{\text {smax }} / h$ and $l_{\text {smax }} / L$ around the supporting piles are 0.07 and 0.08 . Also, $D_{\mathrm{dmax}} / \mathrm{h}$ shoreward is 005 . For the third model, there are two basic scour holes; the biggest one occurs seaward with $\mathrm{D}_{\text {stmax }} / \mathrm{h}$ and $\mathrm{I}_{\text {smax }} / \mathrm{L}$ of 0.15 and 0.16 . While the other one occurs shoreward with $\mathrm{D}_{\text {smax }} / \mathrm{h}$ and $\mathrm{I}_{\text {smax }} / \mathrm{L}$ of 0.09 and 0.12 . Also, there are basic accretion zone under the model with $\mathrm{D}_{\text {dmax }} / \mathrm{h}$ of 0.09 . Also, the maximum shoreward accretion height $\left(D_{\text {dmax }} / h\right)$ is 0.03 .

Figure (9) shows the effect of the three breakwater models on the seabed deformation when the dimensionless wave number $(\mathrm{kh})$ is 0.26 . The figure shows that many crosion zones occur around the supporting piles for the first and the second models, figures (9a) and (9b). Also, there are basic accretion zone occurs near shoreward the first and second models. The maximum relative erosion depth, scour hole length and shoreward accretion height $\left(D_{\text {smax }} / \mathrm{h}, \mathrm{I}_{\text {smax }} / \mathrm{L}\right.$ and $\left.\mathrm{D}_{\text {dmax }} / \mathrm{h}\right)$ are $0.05,0.01$ and 0.04 for the first model and 0.09, 0.04 and 0.1 for the second model. Also, the figures show that the effect of the third model on the seabed is very small and it can be neglected.

Figure (10) presents the longitudinal seabed sections at the middle of the wave flume around the three breakwater models for different wave 


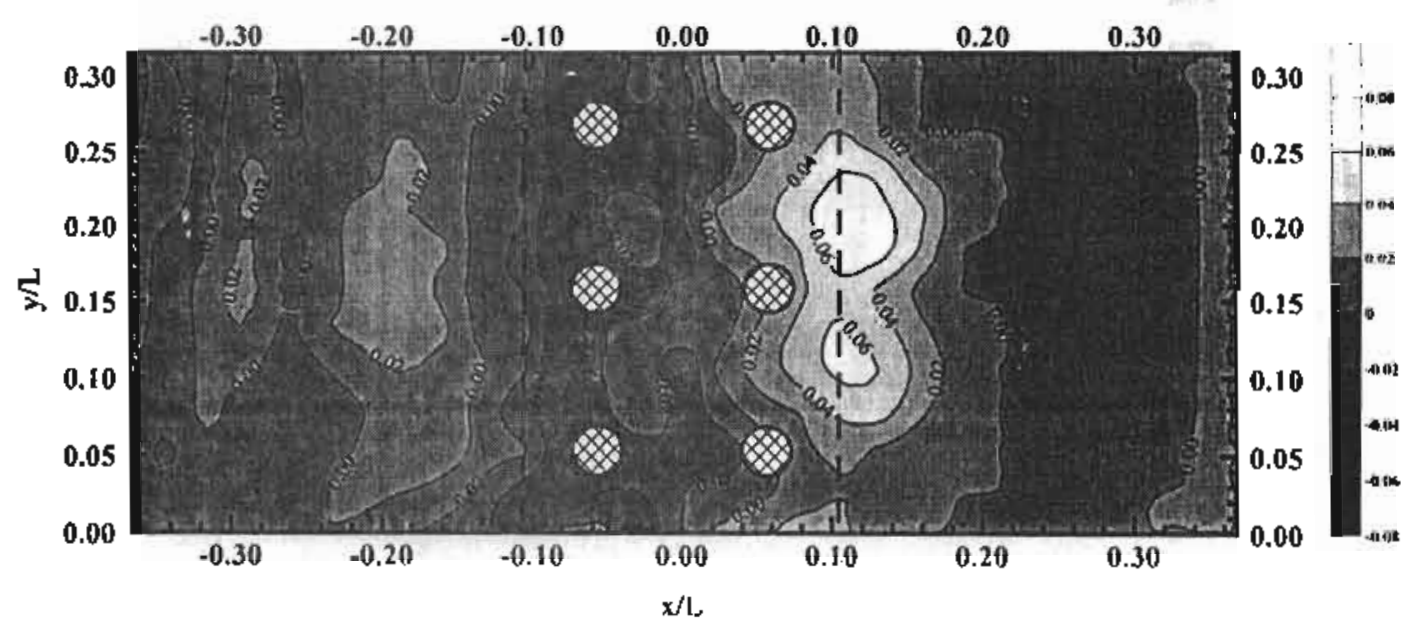

(a) $\mathrm{D} / \mathrm{h}=0.2$ (Caisson Supported on Closcly Spaced Piles)

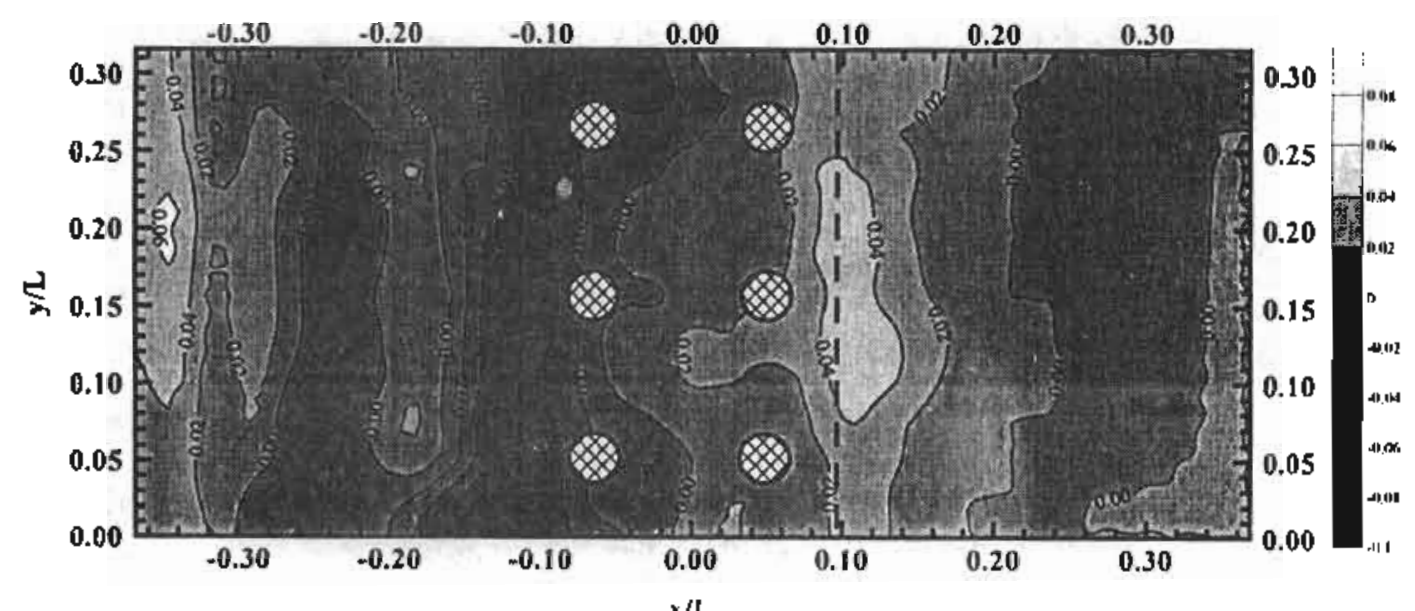

(b) $\mathrm{D} / \mathrm{h}=0.4$ (Caisson Supported on Closely Spaced Piles)

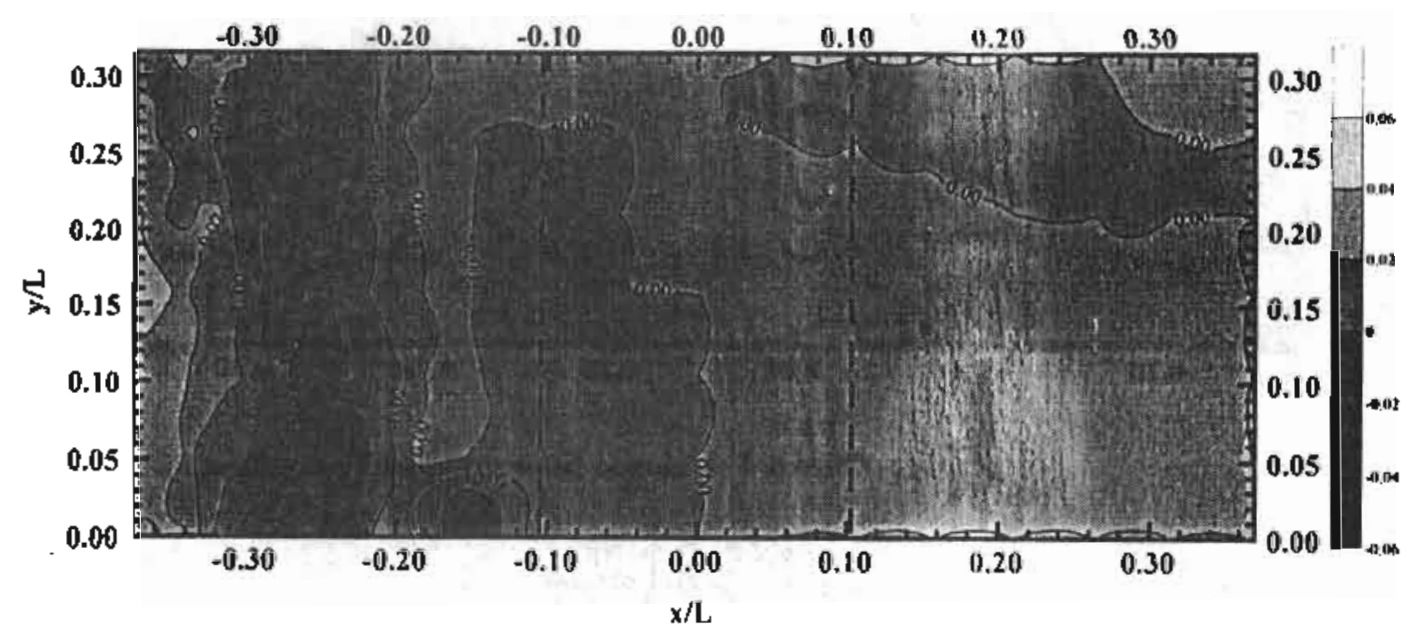

(c) $\mathrm{D} / \mathrm{h}=0.4$ (Caisson Suppurted on Large Spaced Piles)

Fig. (7) Contour Maps of the Seabed Changes Around the Different Caisson Breakwater Models when $k \mathrm{l}=1.32$. 


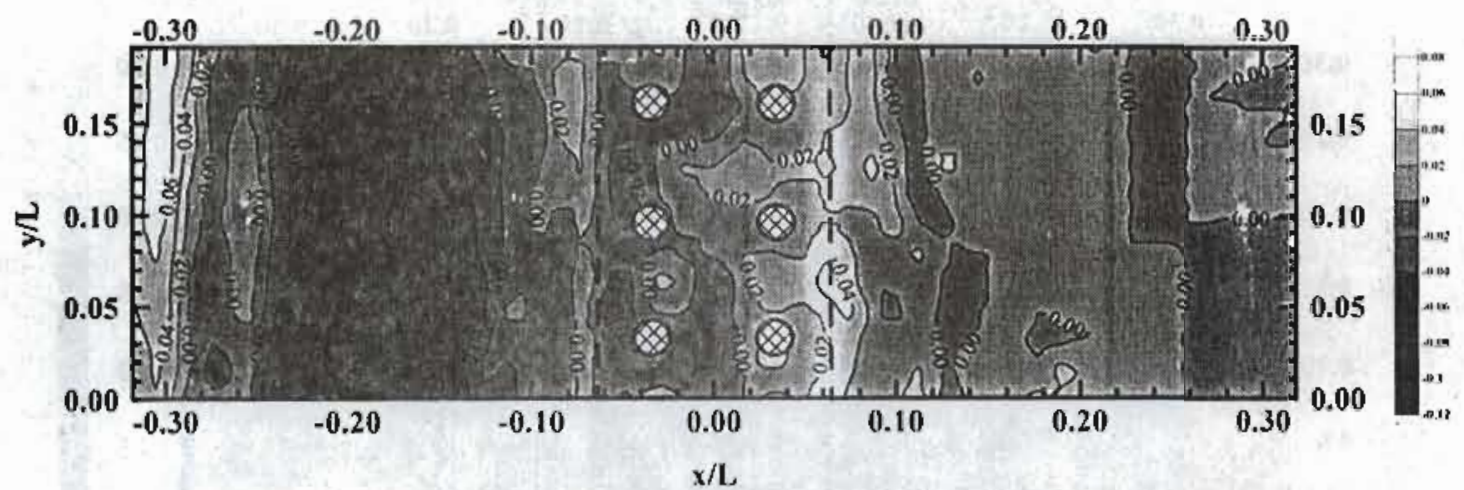

(a) $\mathrm{D} / \mathrm{h}=0.2$ (Caisson Supported on Closely Spaced Piles)

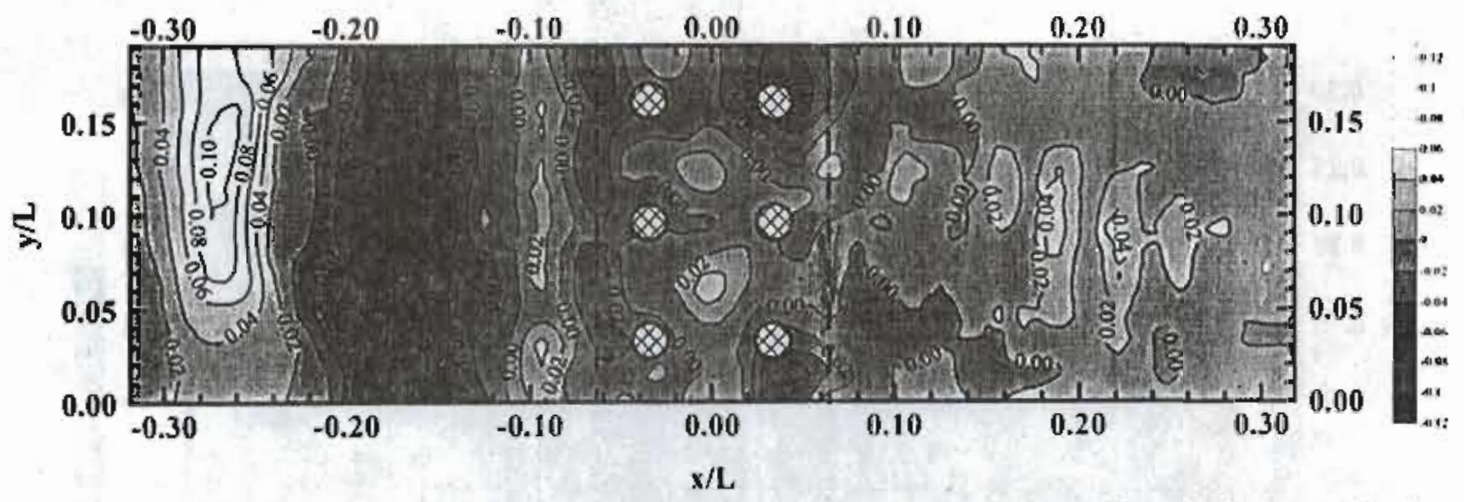

(b) $D / h=0.4$ (Caisson Supported on Closely Spaced Piles)

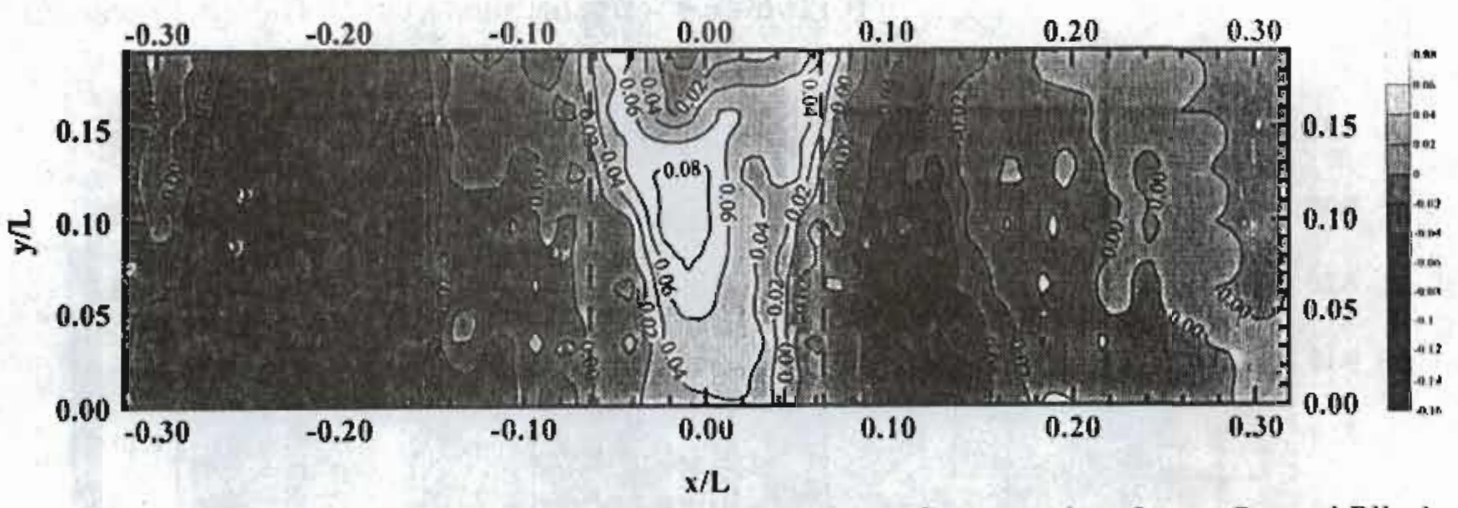

(c) $\mathrm{D} / \mathrm{h}=0.4$ (Ciisson Supported on Large Spaced Piles)

Fig. (8) Contour Maps of the Seabed Changes Around the Different Caisson Breakwater Models when $\mathrm{kh}=0.80$. 


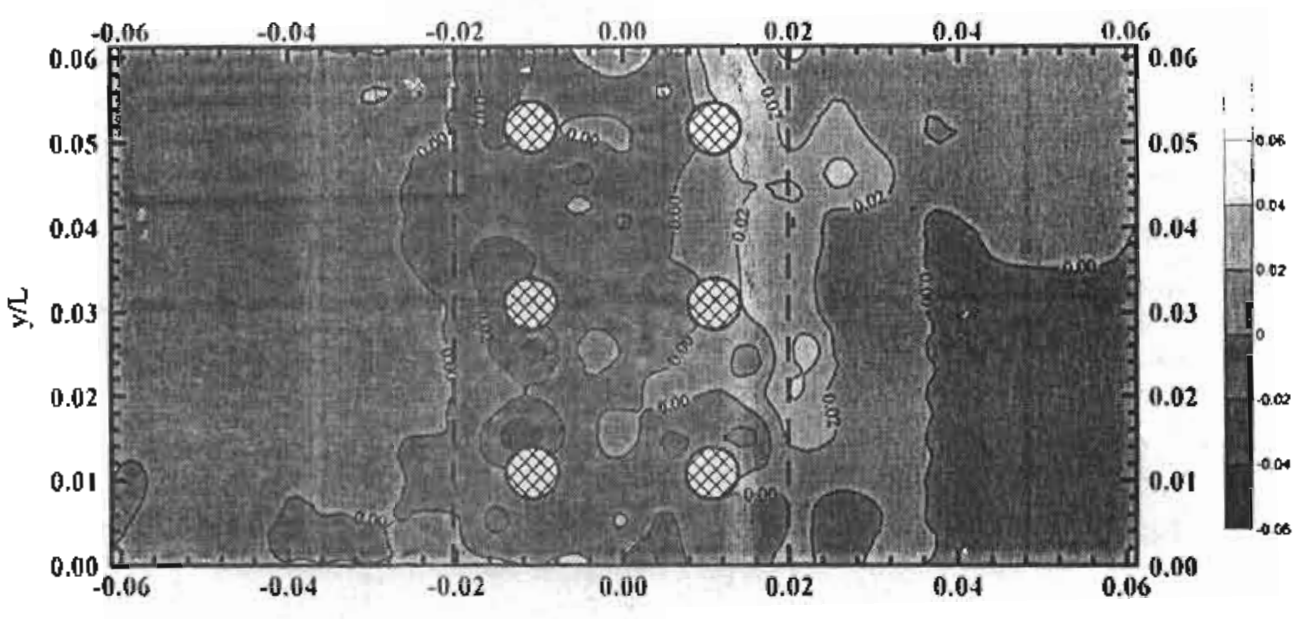

$x / L$

(a) $\mathrm{D} / \mathrm{h}=0.2$ (Caisson Supported on Closely Spaced Piles)

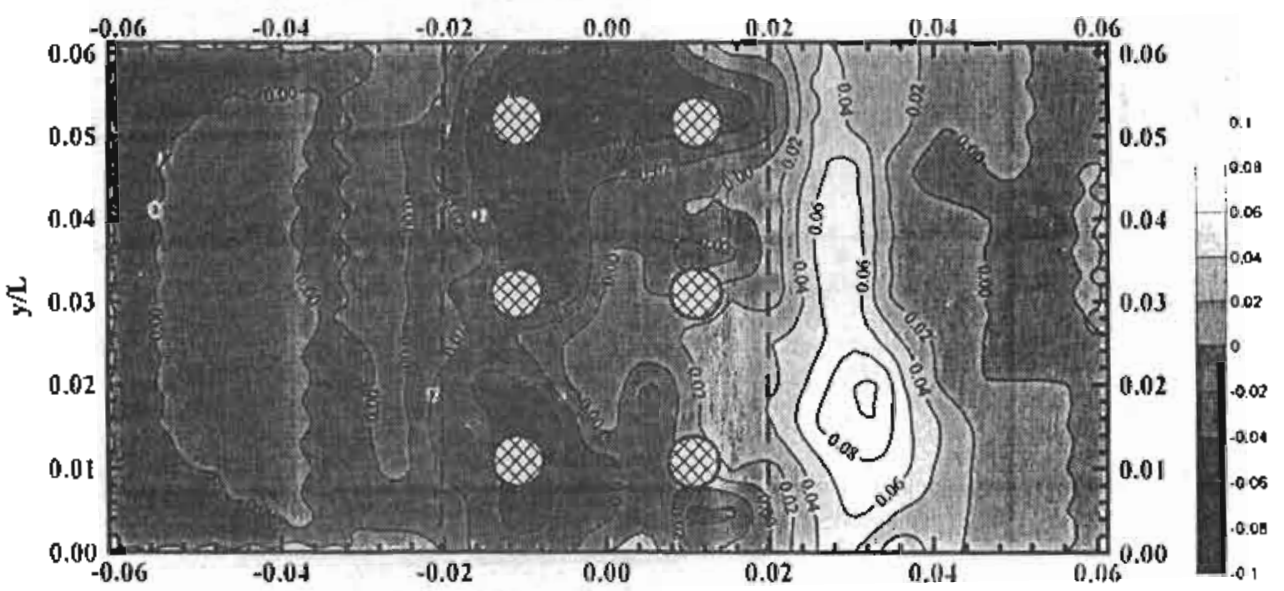

$\mathrm{r} / \mathrm{L}$

(b) $D / h=0.4$ (Caisson Supporled on Closely Spaced Piles)

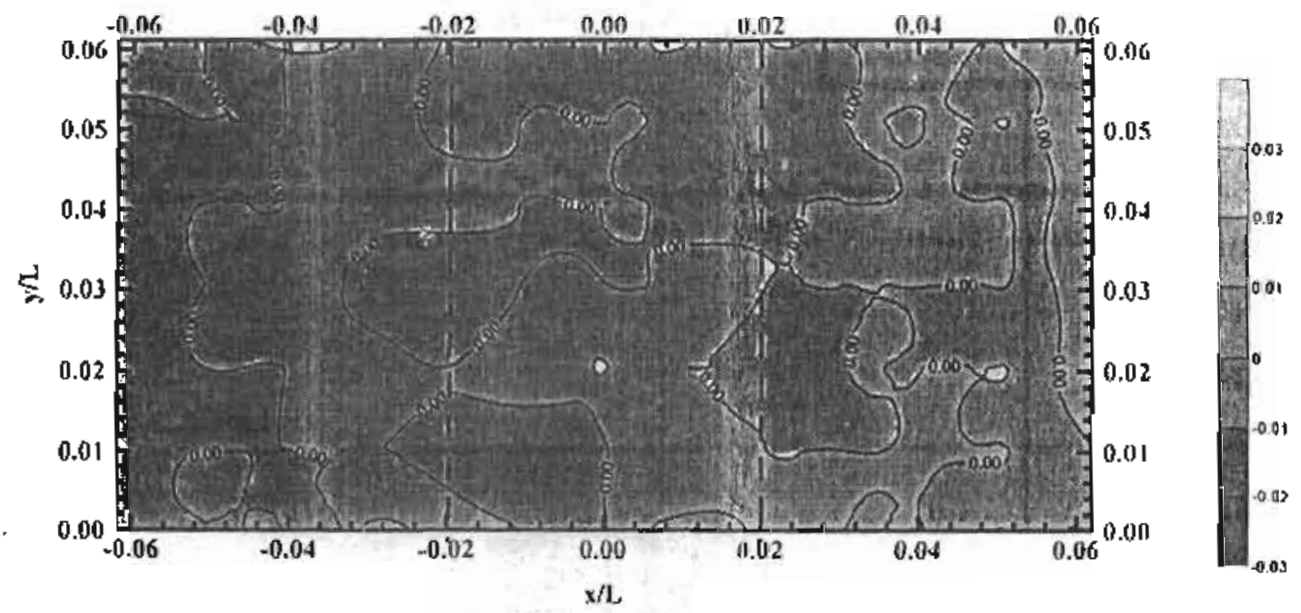

(c) $\mathrm{D} / \mathrm{h}=0.4$ (Caisson Supported on Large Spaced Piles)

Fig. (9) Contour Maps of the Seabed Changus Around the Different Caisson Breakwater Models when $k l_{1}=0.26$. 

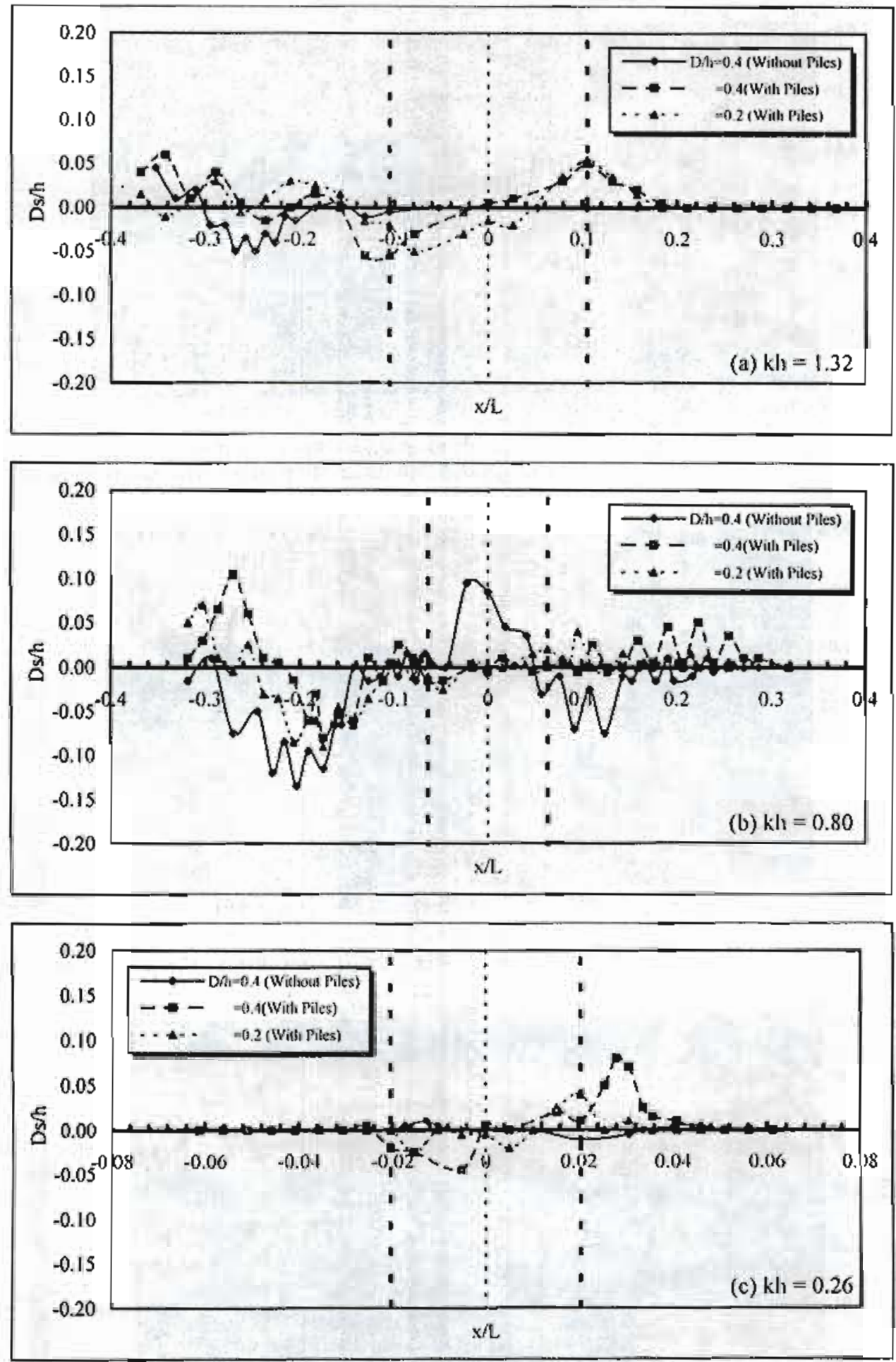

Fig. ( 10 ) Longitudinal Sections in the Seabed at the Midel of the Wave Flume Around the Breakwater Models for Different Wave Conditions 
conditions. The figure shows that the bed profile is not uniform due to the high turbulence caused by the partial standing waves formed due to the interact between the incident and the reffected waves, besides the horseshoe vortex in front of the structure and the wave breaking.

Figure (11) shows the maximum dimensionless bed erosion depth senward three models $\left(D_{\text {snas }} / h\right)$ versus the dimensionless wave number $(\mathrm{kh})$. The results indicate that the maximum equilibrium erosion depth increases when $\mathrm{kh}$ increases up to $\mathrm{kh}=0.62$ then it begins to decrease. This is due to the maximum bottom pressure and increasing of the wave orbital velocily [8]. The maximum relative erosion depth $\left(D_{\text {smax }} / t\right)$ ranged between 0.13 and 0.15 when the dimensionless wave number $(\mathrm{kh})$ ranged between 0.6 and 0.8 .

Figure (12) shows the maximum dimensionless seaward erosion hole length $\left(I_{\text {smax }} / L\right)$ versus the dimensionless wave number $(k h)$. The resulis indicate that the scour hole length increases as kh values increase for the first and second models. While for the third model, it increases as $\mathrm{kh}$ values increase up to $\mathrm{kh}=0.62$ then it begins to decrease. Figure (13) shows the maximum dimensionless bed accretion height shoreward the three models $\left(\mathrm{D}_{\mathrm{dmax}} / \mathrm{h}\right)$ versus the dimensionless wave number $(\mathrm{kh})$. For the first and second model, the maximum dimensionless bed accrction height slowly decreases as $\mathrm{kh}$ increases up to $\mathrm{kh}=1.0$ then increases. While for the third model, the maximum dimensionless bed accretion height increases as $\mathrm{kh}$ increases up $10 \mathrm{kh}=0.62$ then it begins to decrease.

Figures (14) and (15) show the maximum dimension]ess bed erosion depth and scour hole length $\left(D_{\text {smax }} / \mathrm{h}\right.$ and $\left.\mathrm{I}_{\text {snax }} / \mathrm{L}\right)$ around the piles versus the dimensionless wave number $(k h)$. The results indicate that the maximum equilibrium crosion depth reaches maximum value when $\mathrm{kh}=$ 0.62 . Also, the scour hole length increases as kli values increase

Figures (16) and (17) show the maximum dimensionless bed erosion depth and scour hole length $\left(D_{\text {smax }} / \mathrm{h}\right.$ and $\left.t_{\text {smax }} / L\right)$ around the piles versus the Shield's Parameter $(\theta)$. Figure (16) shows that the maximum equilibrium erosion depth $\left(\mathrm{D}_{\text {smax }} / \mathrm{h}\right)$ decreases as the Shield's Parameter $(\theta)$ increases. Figure (17) shows that the maximum scour hole tength $\left(I_{\text {smax }} / L\right)$ increases as the Shield's Parameter $(0)$ increases.

\section{CONCLUSIONS:}

Series of experiments were carried oul to study the effect of the characteristics of the supporting pile systen which were fixed to the semi-immersed caisson breakwater on the breakwater efficiency and seabed changes. The summary of conclusions is:

1. The effecl of the supporting pile system on the breakwater efficiency decrcased as the waves becane shorter. the distance between piles increased and the pile diameter was decreased.

2. The supporting pile system increased the elliciency of the break water by 5 to $20 \%$ according to the number of piles per unit length of the break water.

3. The maximum relative seaward erosion depth $\left(D_{\text {snax }} / \mathrm{h}\right)$ ranged between 0.13 and 0.15 . Also, the maximum relative scour hole length $\left(l_{\text {smax }} / L\right)$ ranged belween 0.12 and 0.15 . This is when the dimensionless wave number $(\mathrm{kh})$ ranged between 0.6 and 0.8 .

4. The maximum relative erosion depth around supporting piles ( $D_{\text {smax }} / h$ ) ranged between 0.08 and 0.12 when the dimensionless wave number $(\mathrm{kh}$ ) ranged between 0.6 and 0.7 .

5 . The maximum relatjve scouz hole length around the supporting piles $\left(l_{\text {smax }} / L\right)$ incrcases as the dimensionless wave 


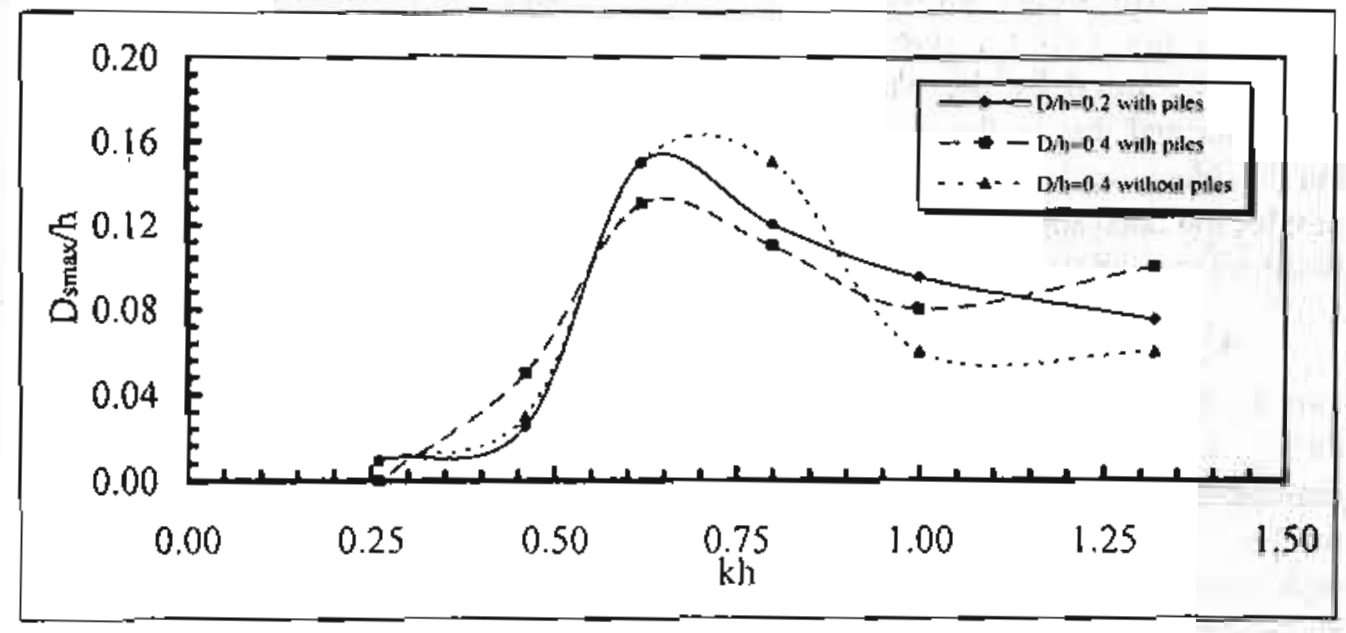

Fig.(11) The Effect of the Dinensionless Wave Number (kh) on the Maximum Dimensionless Seabed Erosion Depth $\left(D_{\text {smax }} / 1\right)$ Seaward Structure.

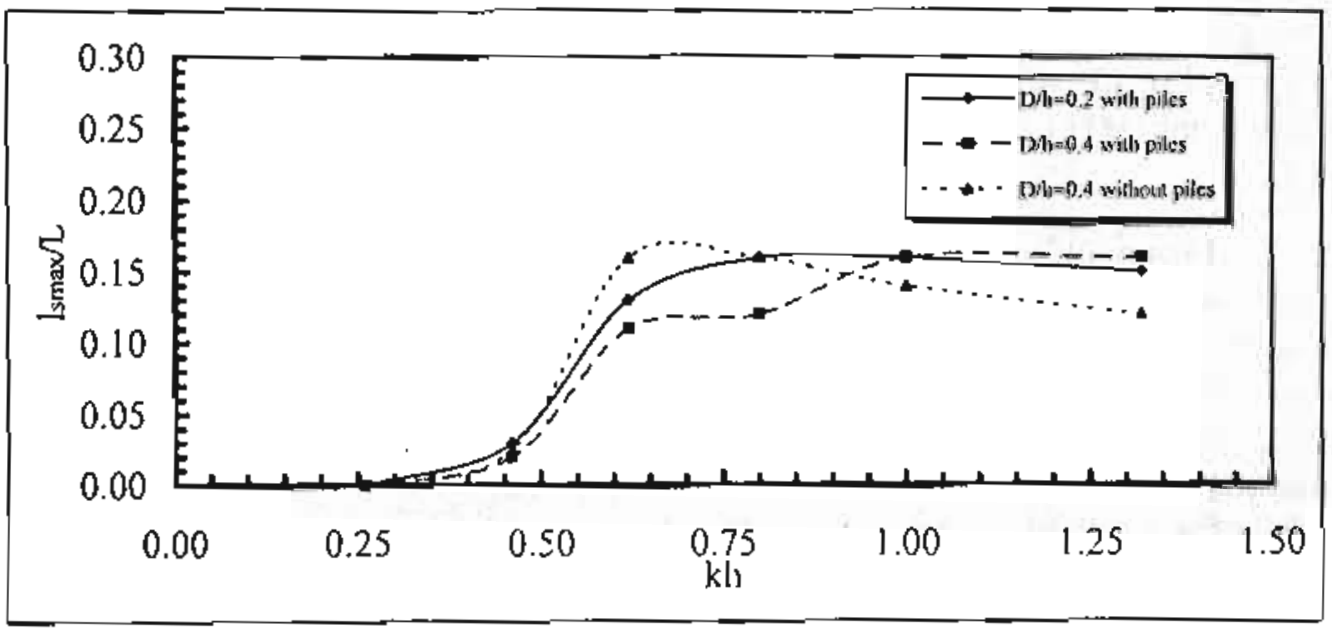

Fig.(12) The Effect of the Dimensionless Wave Number (kh) on the Maximum Dimensionless Seabed Erosion Hole Lenglh (Isnav/L) Scaward Siructurc.

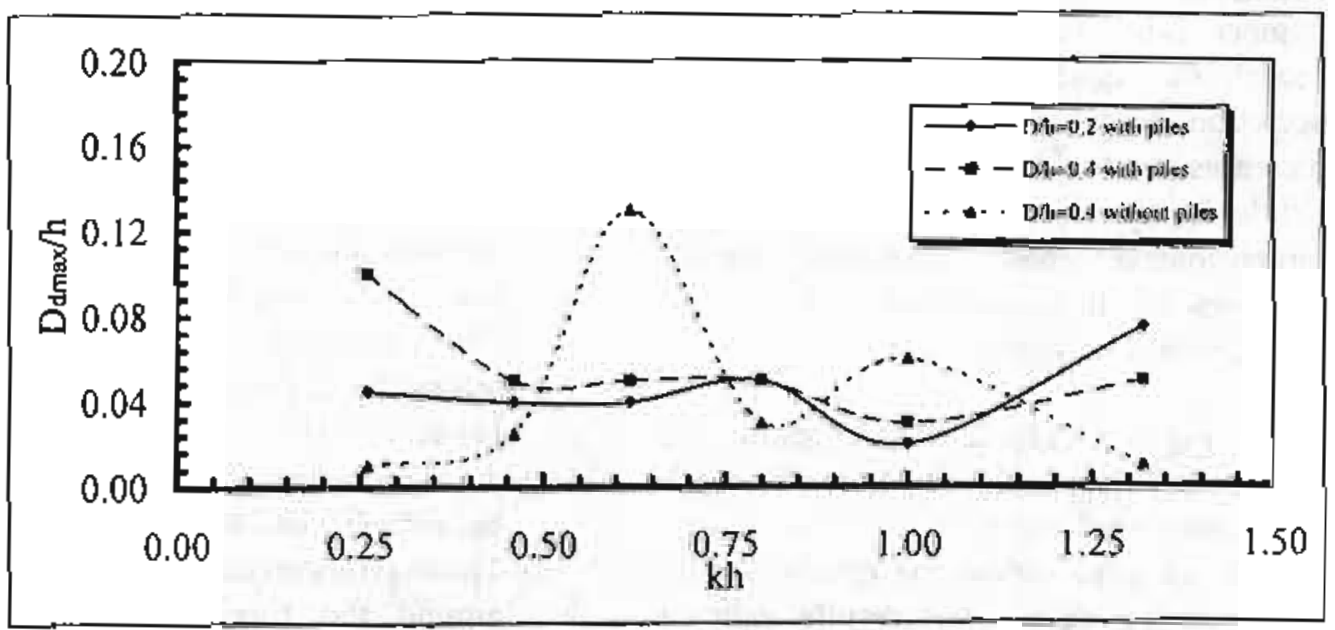

Fig.(13) The Effect of the Dimensionless Wave Number $(\mathrm{kh})$ on the Maximum Dimensionless Seabed Accretion Hieght ( $\left(D_{d \max } / h\right.$ ) Shoreward Structure. 


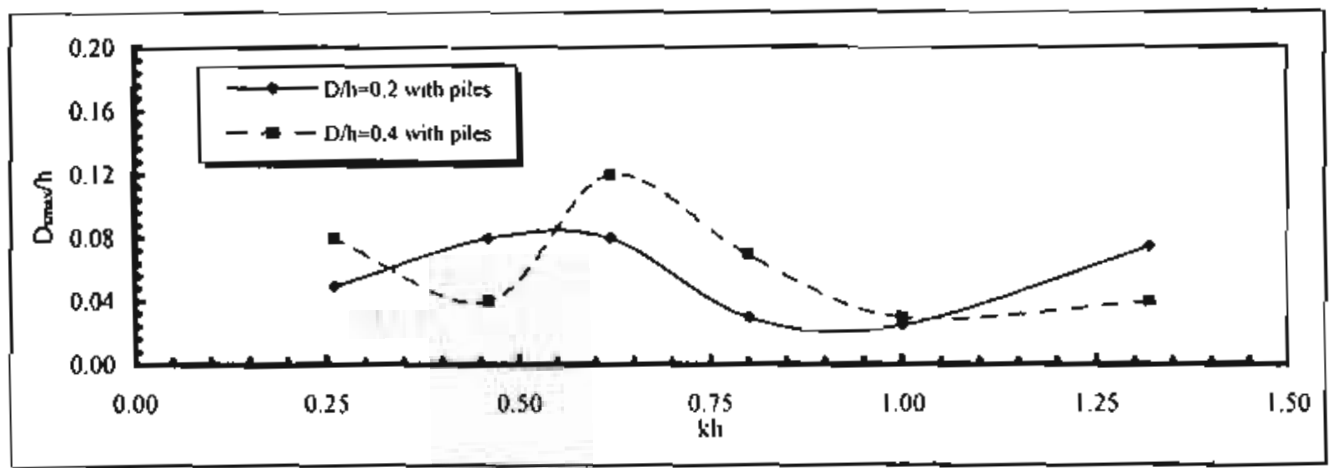

Fig.(14) The Effect of the Dimensionless Wave Number (kh) on the Maximum Dimensionless Seabed Erosion Depth $\left(\mathrm{D}_{\text {sux }} / \mathrm{h}\right)$ around piles.

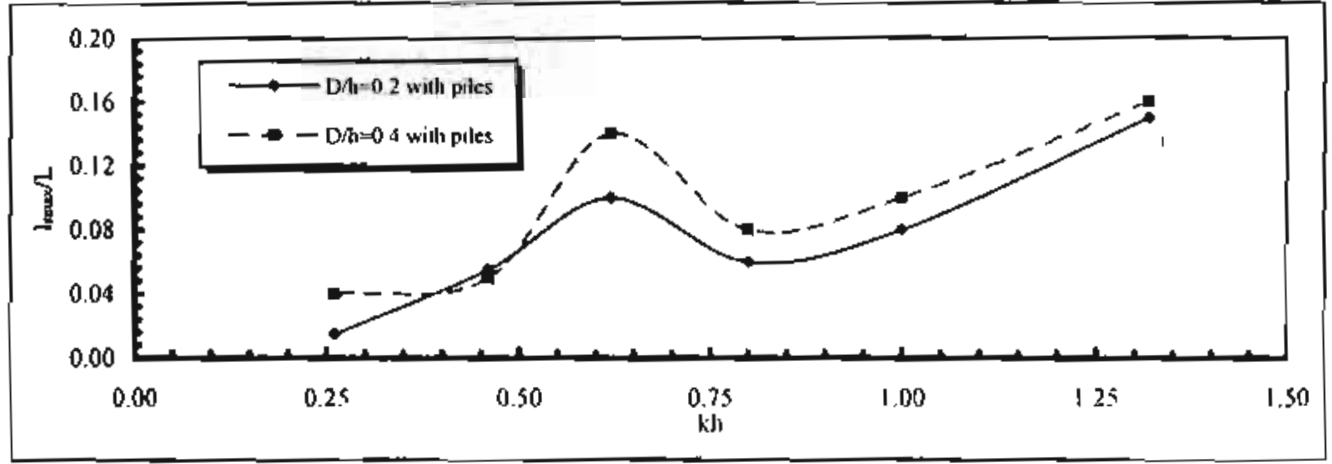

Fig.(15) The Effect of the Diniensionless Wave Number (kh) on the Maximum Dimensionless Seabed Erosion Hole Lengih (Ismax/L) around piles.

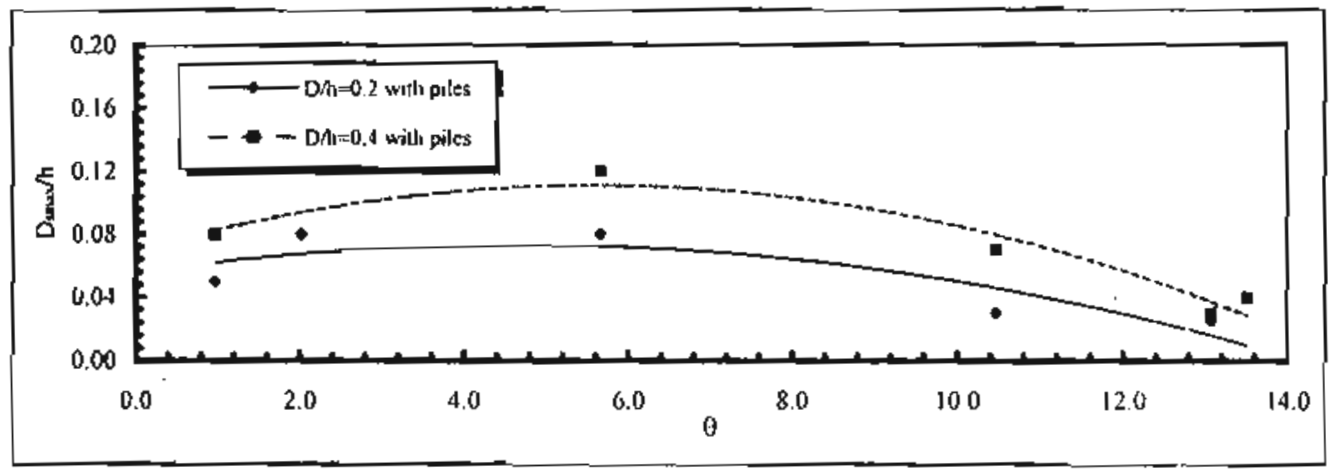

Fig.(16) The Effect of the Shield's Parameter $(\theta)$ on the Maximum Dimensionless Seabed Erosion Depilh ( $\mathrm{D}_{\text {stax }} / 1$ ) around piles.

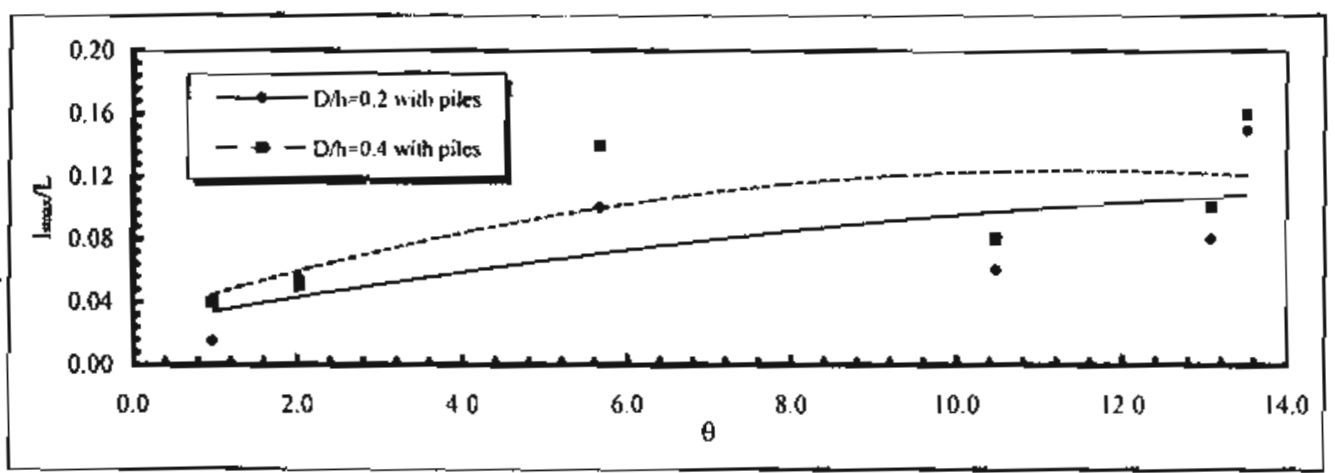

Fig.(17) The Effect of the Shield's Parameter (0) on the Maximum Dimensionless Seabed Erosion Hole Leng(h (limav/L) around piles. 
number (kh) was increased especially when the breakwater draft was increased.

6. The maximum seabed accretion height shoreward ranged between 0.075 and 0.13 relative to the water depth.

7. The maximum equilibrium crosion depth $\left(\mathrm{D}_{\text {sinax }} / \mathrm{h}\right)$ around the supporting piles decreased as the Shield's Parameter $(\theta)$ was increased.

\section{REFERENCES:}

1. Bayram, A. and Larson, M. (2000) "Analysis of Scour Around A Group of Vertical Piles In The Ficld" j. WPCOE, vol. 126, No. 4.

2. Chow, W. Y. and Herbich, J. B. (1978) "Scour Around a Group of Piles" Proc. Off-Shore Technol. Conf., Paper No. 3308, Dallas, Tex.

3. Heikal, E.M. and Koraim, A.S. (2004) "Shore Protection Using a Fixed Floating Rectangular Breakwaters" The Egyptian J. for Eng. Sciences and Technology, Faculty of Eng., Zagazig Univ. Vol. 8, No. 1.

4. Hcikal, E. M. (2004) "Local Sea Bed Scour at Vertical Piles Superimposed by a Seni-Inmersed Body" Scientific Bulletis, Facully of Engineering, Ain Shans Univ., Part I, Vol. 39 ,No. 2.

5. Kobayashi, T. and Oda, K. (1994) "Experimentas Study on Developing Process of Local Scour Around a Vertical Cylinder" Proc. 24t" Jut. Conf. On Costal Eng., Vol. 2, Ch. 93.

6. Maui, J. S. (1991) "Design of Y-Frame Floating Breakwater" j. WPCOE, Vol.117, No. 2.

7. Mani, J, S. and Murali, J.S. (1997) "Performance of Cage Floating Breakwater"j. WPCOE, Vol.123, No. 4.

8. McDougal, W.G, and Sulisy, W. (1989) "Seabed Stability Near Floating Structures"j. WPCOE, Vol. 115, No. 6 .

9. Sumer,M, Fredsqe,J, and Christiansen,N. (1992) "Scour Around Vertical Pile In Waves" j. WPCOE, vol. 118 , No. 1.
10. Sumer,M, and Fredsqe,J (1993) "Influence of Cross Section on Wave Scour Around Piles" j. WPCOE, vol. 119, No. 5.

II. Sumer,M, and Fredsqe, J (1998) "Wave Scour Around Group of Vertical Piles" j. WPCOE, vol. 124, No. 5.

12. Sundar, V., and Subbarao, B. V. V. (2003) "Hydrodynamic Performance Characteristics of Quadrant Front-Face Pile-Supported Breakwater" $\mathrm{j}$. WPCOE, Vol. 129, No I.

\section{LIST OF SYMBOLS:}

a : The wave amplitude " $\mathrm{a}=\mathrm{H}_{i} / 2$ "

D : The breakwater draft

B : The brcakwater width

$\mathrm{D}_{\mathrm{b}} \quad$ : Thic seabed deformation

$D_{d} \quad$ : The accretion height

$D_{s} \quad$ : The crosion deptls

Dumax : The maximum accrelion lecight

$D_{\text {smax }}$ : The maximum erosion depltı

d : The piles diameter

$d_{50} \quad:$ The effective grain size of sand

f : The friction coeflicient

G : The spacing between piles perpendicular to wave direction

g : The gravitational acceleration

$\mathrm{H}_{\mathrm{i}}$ : The incident wave height

$\mathrm{H}_{\mathrm{r}}$ : The reflected wave height

$H_{1}$ : The transmitted wave height

h : The water deptl)

$k$ : The wave number " $k=2 \pi / L$ "

$k_{1}$ : The transmission coefficient

$\mathrm{L} \quad$ : The wave length

$I_{\text {snax }}:$ The maximum erosion hole length

$R_{n} \quad$ : The Reynolds's number

$S$ : The spacing between piles parallel to wave direction

$\mathrm{s}_{\mathrm{b}} \quad$ : The seabed slope

$s_{\tau} \quad$ : The sediment relative density

$\mathrm{T} \quad$ : The wave period

$\mathrm{U}_{f \mathrm{n}}$; The maximum value of the undisturbed bed shear velocity

$\mathrm{U}_{\mathrm{m}}$ : The maximum orbital velocity

$v$ : The kinamatic viscosity of water at $20^{\circ} \mathrm{c}$ " $\mathrm{v}=1 \times 10^{-6} \mathrm{~m}^{2} / \mathrm{sec}$."

0 : The Shields parameter

$\omega$ : The angular wave frequency 